$$
\begin{aligned}
& \text { II) } \\
& \text { () } 19
\end{aligned}
$$

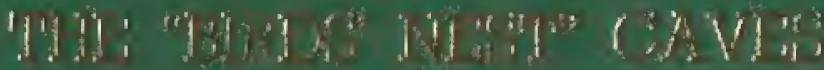$$
\text { (A) }
$$

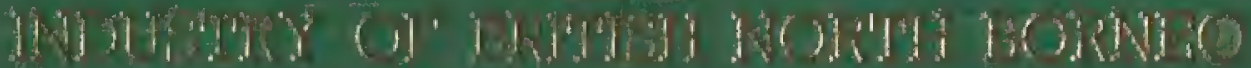

\title{
(o) dotide
}

\section{$C A$}

MTR 598,89

(1) $\lambda$ 
NATIONAL UBRAFY SINGAFORE mo 



\section{I- ast ant?}

REPORT

$0 \%$

\section{'HE "BIRJS" NEST" CAVES \\ AND}

\section{INUUSTRY OF BRITISH NOR'IH BORNEO}

With Special reference to the Gomantang Caves

By F. N. Ohasex

Ourutur of the Rafines Musam, Singapre

JESEELTON,

Printed at tho fiovertment Printivg Offer, North Burnen.

$\overline{1691_{1}}$

CHA. 


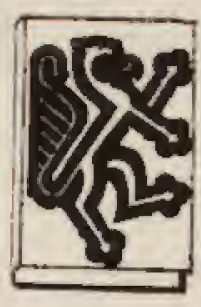

The DR. CARL ALEXANDER GIBSON-HILL, COLLECTION

(born 1911: died 1963)

presented to the

NATIONAL LIBRARY OF SINGAPORE

by

MRS. LOKE YEW

in fulfilment of the intention of her son

LOKE WAN THO

(born 1915: died 1964) 


\section{CONTENTS.}

Page.

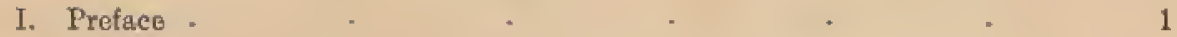

1I. Introduction $\quad$ - $\quad$ * $\quad$ * $\quad$.

1II. Local inportance of the industry as shown by statistics - $\quad 3$

IV. Existing fallacies + - * * * 8

F. Systematic - - * + . 4

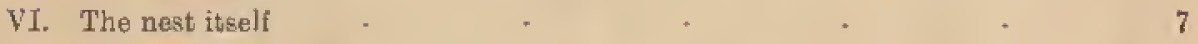

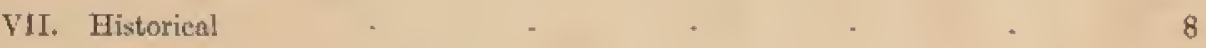

VIII. The North Borneo Caves - . $\quad$ - 9

IX. The Gomantong Caxes - - - $\quad 10$

X. Communientions . . . $\quad$. 12

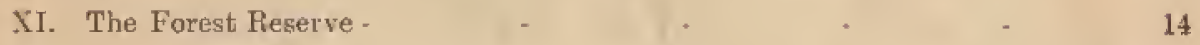

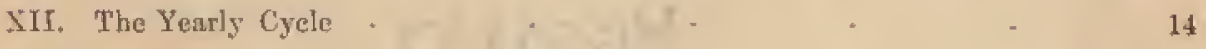

IIII. Food of the Swiftlets - - $\quad$ - $\quad 16$

XIV. Infant Mortality . . . . . . 17

XV. Other inhabitants of the enves: Enemies - . 17

XVI. Guano and $\operatorname{Lggs}$. . . . . 19

XVI. Methors of collecting the nests - . $\quad 19$

XVIII. Marketing - * * * + $\quad 21$

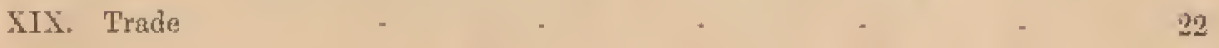

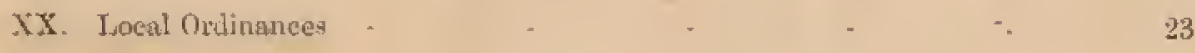

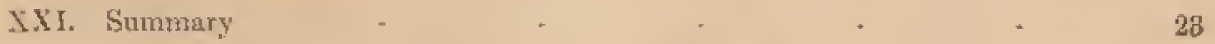




\section{NATIONAL LIBRARY; SINA IPORE. \\ 29 JULL 1613705 \\ MR598.89 \\ CHA}




\section{PREPACL.}

This report is the result of a visit to British North Borneo in July 1929 undertaken with the permission of the Govermment of the Straits Settlements at the request of the late Mr. J. L. Humphreys, C.M.G., C.B.E., then Governor of the Chartered Company's territory.

'I'he Gomantong Caves were visited and the official records of untter's relating to the caves and the associated industry were examined.

I must express my gratitude to the ofticials of the Chartered Company : the least of many kindness shown to me during ny stay in Borneo was the manner in which the accunulated experjence of many years was placed at my disposal. In particular I must mention the Hon. Mr. J. Maxwell Hall, the Resident of Sandakan and Mr. W. J. Phillips, Assistant District Ofticer, in whose administrative area the caves are situated.

Unfortunately the Conservator of Forests was not in Sandakan at the time of my visit.

The following pages contain much that is admittedly only of academic interest but this apparently extrmeous matter has been purposely introduced in an attempt to invest the subject with a certitin amount of interest calculated to appeal to officers administering the caves in futnre. 'The purely practical portions containing the recommendations $I$ have ventured to make are introduced in their appropriate place but for convenience the more important of these are summarized in a final section of the report.

It will be noticed that there are statements in the following pages based solely on native testimony. At this early stage of a serious study of the Gomantong caves no other sorurce of information is available. It is almost unneccssary to point out that knowledge so acquired can never be regarded as absolutely authentic.

Singapore, Ist March, 1930.

F. N. CHASEN. 


\section{INTHODUCIION.}

In the architecture of the nests of many birds a secretion of the salivary grands plays a part but it remains for some members of the family Micropidae, or Swifts, to make their nests largely or wholly of inspissated saliva which hardeningr into a substance not unlike isinglass on its exposuce to the air forms the "edible birds' nests" of conmerce. 'I'hese nests are in great demand by epicures, chiefly Chinese, by whom they are supposed to be aphrodisiacal.

It is a fortuitous but fortunate circumstance for North Borneo that the birds providing the nests elect to nest in large colonies in that country.

T'echically, the nests in the caves of North Borneo are produced by four species of swiftlet (a name of no real significance but merely a popolar diminutive of swift"). These are all of the genus Cullocalia, a division of the Chacturinae which is at subfanily of the Micropidae containing in addition to the "Swiftlets" the well known spine-tailed swifts, one of which is supposed to be the fastest bird in the world.

The nests are collected by natives at regular intervals and eventually exported from the country, manly to China. The Government profits by the export tax paid on the nest and by the reception of a variable royalty. "The industry appears to be permanent and it is lucrative to all parties.

\footnotetext{
"On no aceonut nust" swallow" be sulsatituted for swift or swiftlet.
} 


\section{LOCAL IMPORTANCE OF THE INDUSTRY AS SHOWN BY STATISTIGS.}

It is unnecessary to emphasize the great local importance of the birds' nest industry but, although the value of an industry cannot be entirely estinated by it consideration of its purely monetary returns, the following figures kindly supplied by the Hon. Mr. M. M. Clark, the Commissioner for Custons and 'Trade, enable one to visualize its place in the commerce of the country and to appreciate that it is not only worthy of the serious consideration it receives on the part of the administration but also of a certain anount of alditional fostcring.

The position of the North Bornean industry from the point of view of world trade is discussed in a later section of this reprort.

During the last three years the Government royalties from birds' nests have been as follows:-
1928
$\$ 46,948.00$
$\$ 38,587.00$
1926
$\$ 39,497.00$

These royalties are obtained in two ways:-

(a) Certain caves are the property of the State and, excluding some minor adjustments, the Government draws 50 per cent of the total proceeds.

(b) Other caves are recognised as private property (that is of individuals, communities or tribes) and are subject to an annual toyalty of 10 per cent of the nests collected.

The Gomantong caves, the largest and most important in the country, are owned by the State and the Government share of the proceeds from then for the last four years as shown by figures in the liesident's Oftice, Sandikan, is :-

\begin{tabular}{lll|lll}
1929 & $\ldots$ & $\$ 45,685.22$ & 1927 & $\ldots$ & $\$ 32,095.91$ \\
1928 & $\ldots$ & $\$ 43,546.86$ & 1926 & $\ldots$ & $\$ 33,041.04$
\end{tabular}

In addition to the royalties the Custons collected the following export duty:-

\begin{tabular}{lll|lll}
1928 & $\ldots$ & $\$ 12,849.00$ & 1926 & $\ldots$ & $\$ 10,825.00$ \\
1927 & $\ldots$ & $\$ 11,079.00$ & & &
\end{tabular}

\section{EXISTING FALLACIES.}

It is hoped that this report will disperse many mistaken ideas, widespread in Borneo, concerning the swiftlets and their economy and thus stimulate an interest in their habits based on the right notions. Fallacious ideas are by no means confined to North Borneo, where even the well informed natives of Bilit consider that the exceptionally fine white nests found on Berhala Islet in Sandakan Bay are due to a very favourable environment.

Many of the old ideas concerning the composition of the material of which the nests are made, the cause of the various kinds of nest, the correlation of the quality of the nests with the local food supply, the hypothetical migrations of the birds in the non-breeding season and even the suecific identity of the birds have died very hard, and indeed are in some cases, not yet dead and have found their way into official reports one of which published in 1923 contained the following astonishing statement :-

"The Swift collects the material-gelatinous wormlike organisns-from the surface of the sea." 


\section{SYSTEMATIC.}

The geographical range of the genus Collocalia covers India and Ceylon, thence south to the Seychelles and Mauritius and east through Malaysia and the Plilippines to the Islands of the Marianane, Marquesas, Society and Tonga groups and even to northern Australia.

In widely scattered localities within this large range the nests of several species are worked for profit under conditions noted in greater detail below.

Five species of the genus occur in Malnysia. Four of these are found in Borneo and examples of each species together with their nests were examined during the recent investigations.

The fifth species is Collocalia gigas, the largest member of the genus. Very little is known about this rare bird: only a few specimens are known and these have been olttiined in the highlands of the Malay Peninsula, Sumatra and Java. It is reasonable to suppose that it also occurs in Borneo but even if it is eventually proved to exist there the species is never likely to be of economic importance.

The four species with which the North Bornean industry is concerned are represented by the following forms :-

\section{Collocalia brevirostris lowi (Sharpe) \\ Collocalia fuciphaga amelis Oberholser \\ Collocalia francica mearnsi Oberholser \\ Collocalia esculenta cyanoptila Oberholser}

\section{Collocalia mevirostris lowi (Sharpe).}

Hitherto known as $C$. lowi. It is now suggested that in all official documents, except those intended for publication in which the full technical designation should be printed, this bird should be known as "T'HE BLACK-NEST SWIFTLET,"

This is the species responsible for the black nests throughout the country.

Characters-A small dark bird, slightly glossy on the wings and tail. The upper parts are brownish black but the under parts are rather paler or brownish grey in colour. The feet (tarsi) are strongly feathered and wing pressed that against a ruler measures from 124 to $137 \mathrm{~mm}$. (see fig. 1). Birds from southeastern Borneo are said to be rather smaller: they have been named tichelmani by Dr. Stresemann.

2. Collocalia fuciphaga amelis Oberh.

Can conveniently be known as "The Common Whitr-Nest Swiftext."

The white nests of the Gomantong caves are made by this species.

Characters.-Very like the last species but smaller: the wing pressed flat against the ruler measures from 116-126 $\mathrm{mm}$. 
It is also rather paler on the miler parts than lowi and has the feet naked or very thinly feathered.

In lowi the outside of the foot is furnished with a row or ruff of feathers and in some specimens the inside of the foot is also feathered (see figs. 2 and 3 ). in loxi.

The degree of fenthering in amelis is a variable feature but it is never as

Some amelis were collected at Gomantong in 1929. One had two fenthers on the outside of the foot; a second had one feather on the outside of one foot; a third had three feathers on the outside of one foot and in others there were a few feathers on both the inside and the outside of the foot. By some authorities the foot is said to be naked.

\section{Coltocalia franctCa Mrarnsi Oberh,}

One example of this species was brought to me from Berhala island in Sandakan Bay. The white-nests from Berhala are of exceptionally fine quality: it seems feasible that mearnsi is scattered round the consts of North Borneo. Nothing has been recorded conceming the nidification of this species and it is curious that a nest, unknown to science, should have been an article of conmerce in Borneo for many years. This species can most appropriately be known as "Mearis White-Nest Swiftlet."

Very little is known about this bird. 'The single specimen from Berhala Island is not unlike the specimens of amelis from Gomantong but it is much darker (more blackened on the back), and has the rump (i. $e$. the part of the back just in front of the tail) distinctly paler than the back. The feet were naked but it is said that they are sometimes feathered.

\section{Coldocalia ESCUlinta cyanoptila Oberh.}

This is the species usually, but erroneously, known as linchi. Popularly it may be known ns "THE WHITE-BELLIED SWIFTLET."

In appenrance it is quite unmistakable. In size it is much smaller than any of the sprecies mentioned above: wing from $100-108 \mathrm{~mm}$. The upper parts are black washed with metallic green: the throat and breast are grey and the abdomen white.

The white-bellied swiftlet is responsible for the mossy nests which are useless from the commercial point of view. Malays call the swifts "Layang-layang" (a name also applied to swallows) but the Sungei folk of the Kinabatangan River use the Suln "Kalam Pisau". The nests are called "proteh", "itam" and "lumut" with the Sulu "Salung" substituted by the Malay "Sarang" (nest).

[In 1914 (Journal of the Straits Branch, Royal Asiatic Society) the late Dr. J. C. Moulton proposed certain popular names for these swiftlets in his 
"Handlist of the birds of Borneo" but his names are not very apt and as there is no obligation to accept priority in such matters the names used above are suggested as substitutes in the hope that they will become faniliar to residents and officials in North Borneo and perhaps stay in the minds of those who have little taste for "technical names".

If the valid technical names of the swiltlets are to be mentioned at all, the modern trinominal system of nomenclature cannot be avoided. Formerly whenever a bird was found to be unlike all other known kinds of bird it was considered to be a "new species" and, upon it, a new specific name was bestowed. It is now recognised that many of the old "species" can be linked up and that they are only slightly altered geographical races of a widely spread "kind" of bird. Their original "specific" names are therefore rednced to "subspecific" or racial names of the first nane applied to any member of the species and thus the trinominal system of nomenclature cane into existence.

The systen can be illustrated in detail by one of the swiftlets. 'The small kind with white abdomen, common in Borneo, is often referred to as $C$. linchi but this is quite wrong: linchi is a name originally applied to a specimen from Java and birds from Java and Borneo are quite different. They are, in fact, both only geographical races of a widely spread species ranging from the Andamans and Nicobars throughout Malaysia and east to New Guinea, New Caledonia and the New Hebrides. No fewer than fifteen races or subspecies of this bird are recognised. The first name applied to any one of them is esculenta of Linné who thus indicated the bird occurring in the Moltuccas. All the races then become subspecies of esculenta and in Malaysia occur:-

C. esculenta cyanoptila-Malay Peninsula, Sumatra, Borneo.
C. e. dodgei
C. e. linchi
C. e. natalis

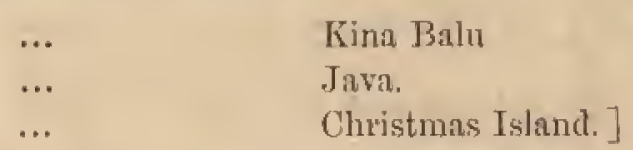

It is undisputed that sound systematic work is an essential preliminary to any biological economic investigation.

Sufficient has alrealy been indicated above for most practical purposes but more birds must be examined from Berhala, other isolated colonies in the Sandakan Residency and a fairly extensive collection from the East Coast caves before it can be considered that we have anything like a complete understanding of the identity of the birds themselves. These collections could be made by a subordinate ofticer of the Forestry Department after a few weeks tuition in field-collecting and taxidermy. Such tuition could probably be obtainer with the assistance of the Director of Museums, S. S. and E. M. S.

Correctly identified specimens of each species should then be mounted, and together with their nests placed on permanent exhibition in the Museum at Sandakan. They could then be regarded as a permanent reference. 


\section{THE NEST ITSELE.}

An immense amount of folk-lore most of it based on inaccurate observation has grown up conceming the composition of the nests and the causes of the different kiuds.

Regarding the first of these it seens unnecessary to do more than quote Prof. Alfred Newton who as long ago as $189 t$ wrote, " ..........nd their composition, though announced many years since by Home, whose statement was confirmed by Bernstein, las of late been needlessly doubted in favour of the popular belief that they were made of some kind of seaweed, Algae, or other vergetrble matter collected by the birds. It may be hoped that the examination and analysis by Dr. J. R. Green (Journ. of Physiol, VI, pp. 40-45) hatve settled that question for all time. These remarkable nests consist essentially of nucus, secreted by the salivaly glands above mentioned which dries and looks like isinglass. Their marketable value depends on their colour and purity, for they are often intermixed with feathers and other foreign substances."

'T'he nest, of whatever quality", consists of the half saucer-like portion ("flesh") and the two expanded buttress-like attachments ("feet").

From observations and enquiries made on the Kinabatangan River I believe the following facts to be well substantiated :-

The white nests are usually formed entirely of inspissated saliva although foreign matter's are sometimes included. In black nests the saliva is largely mixed with feather's etc. The non-edible nests of cyanoptila are composed of moss etc. glued together with a small amount of saliva the foot containing lather: more thun the satucer.

'Tle nests vary in appearance and quality according to which batch they belong but not to the extent believed by some natives. "The first "white" nests are thick aud much tinged with red. The second nest is of a better quality: it is thinner and whiter. The third nest is smaller, very thin and much stained with red. The red stain is chiefly noticeable at the base of the nest where it is attached to the wall. The building of the first nests takes a long time. They are gradually developed and much stnined, no doubt largely by contact with the cave wail before they are gathered. The sccond nest rather thinner, because of the further sustained effort involved on the part of the bird, is made more quickly and is therefore cleaner. The third nest, also thin, is much stained by the young occtuants belore it is taken.

In the case of the black nests the second nests contain more feathers thrn the first nests. They are also thinner, and less valuable: gathering of the third crop of black nests is not considered a commercial proposition.

'I'he commercially ideal nest is very white, entirely free from feather's anit unstained. Local opinion, and the prices realized support the viow, is that Labad Datu nests are better than those of Gomantong although these are very good; but that the best white nests of all come from the tiny islet of Berhalin in Sandiakan Bay. These latter are of very fine quality. The llesh is very white and the feet can also be eaterl. In Gomantong nests the feet are usually red and inedible. We have seen that these first quality nests are the product of $C$. francica nearnsi. The Lahad Datu white-nest builder has yet to be identified. 


\section{HISTOIICAL.}

In the Histoiy of the Ming Dynasty (1368-1643), Book 325, mention is made of birds' nests among the products of Johore: they probably came from the islands off the enst coast of that State. An old regrister kepst at Batavia and dated 1663 also refers to the transport of consigmments of nests. Research would almost certainly produce carlier references.

"Himudo esculenta" was of course known to Linné and Buffon cites a correspondent who, embarking for a voyage to Clum in 1741 , visited some nesting places of "la salangane" near Java. An early and full account of the important caves at Karangbolong in Java is to be found in Crawford's History of the Indian Archipelago, III, 1820 , p. 430 et seq.

The anthor gives some interesting firures concerning the amual export of nests: he attributes to Java 200 piculs or 27,000 lbs. but remarks that the greatest quantity comes from the "Suluk Archipelago" which is credited with 530 piculs : 30 piculs are also attributed to "Maccasar.".

Crawford naively remarks " how the latter (i. $c$. the Chinese) first acquired a taste for this foreign commodity is only less singular than their persevering in it. Among the westerm nations there is nothing parallel to it unless we except the whimsical estimation in which the Romans held some articles of luxury, remarkable for their scarcity rather than for any qualities ascribed to them."

The earliest mention I can find to the North Borneo caves is the indirect reference to the nests from the "Suluk Archipelago" made by Crawford in 1820: this may include the Gomantong caves.

Concerning the Gomantong caves the first name to occur in the days of the Chartered Company is that of Pengeran di Gadong Samala just as often referred to in official documents as Panglima di Gadong. He is sonetimes stated to have been the original owner of the caves, in possessiou when the Govern ment took over, but from an unsigned article in the "North Borneo Herald" II, No. 1, March 1884, p. 3, we learn that the grandfather of "Pangeran Sumn", the latter" an influential Chief of the Kimabatangan district, was the first to work the rich birds' nest caves of Gomantong. 'This ancestor was executed by his sovereign, then Sultan of Sulu, whose authority he had slighted. Of the Pangeran's father nothing is said but we learn that Pangeran Samal himself had the collection of the birds" nest of the Gomantong caves "virtually in his hands". The Government hat accitired from the Sultan of Sulu his large share in the caves, so that it had a principal interest in seeing that the nests were properly collected at the dne times and seasons. The Pangernn seems to have performed his duties in such an unsatisfactory manner that as a last resort the Government decided to take over the collection of the nests into its own hands and to pay to the rightful owners their due shares of the amounts realized. The Pangeran was subsequently lilled offering armed resistance to the Chartered Company which granted an anntity to his daughters. The present Government Agent for the caves is Guliga who is a son of one of the daughter's: Guliga married a daughter of the brother-in-law (Dyte) who was with Pangeran di Gadong when he was hilled but having been 
noted to have taken no part in the affray became administrator of the caves immediately after, having taken the oath of allegiance to the Government. But the mantle of authority has not fallen directly upon Guliga by virtue of his descent and the personnel of the practical administrators of the caves has kuown many vicissitudes.

The actual working system in force for the various enves in the territory is not constant. Some like the Gomantong caves which were confiscated on the denth of Panglima di Gadong are the property of the Government. Contractors are appointed from time to time and these are under the control of a paid Government Agrent. The contractor draws the money and engages the workers in the kampongs who share in the profits.

The Government was formerly paid \$20,000 per annum for the rights to work the caves but the present arrangement is that the Govermment gets a royalty of fifty per cent of the total proceeds ( excluding certain minor adjustments).

From privately owned caves the Government draws an annual royalty of 10 per cent.

On the east coast the collecting rights of the caves are hereditary and registered by Government.

\section{THE NORTH BORNEO CAVES.}

It is much to be regretted that a complete list of the caves or known nesting places of the swiftlets in the territory cannot be given. Such a list would be of great value as a basis for administration and future investigations but it does not yet exist and its compilation would entail an exhaustive enquiry in every Residency of the country and require a much more intimate knowledge of the country than the writer possesses. All the large and easily accessible caves are of course well known but the whereabouts and character of others are very vague and some are, almost without donbt, unregistered. As a first step to any complete investigation I suggest that:

1. (a) A register of swiftlet colonies should be compiled and kept in each district office. It should show the exact location of all colonies and caves together with a certain amount of detail. There seem to be unrecorded casual nesting places, even on the Lower Kinabatangan. The number nay be small but when the price fetched for the fine Berhala nests is considered even small number's cannot be ignored.

(b) The register shonld also record former and reputed nesting places many such "fancies" having a basis of truth.

(c) It should also contain ample space for the observations of a succession of District Ofticers. Such a definite allocation of space would stimulate the energy of such D. O.'s with a taste for such an enquiry. It may be noted that to my certain knowledge a good many District Officers from Kota Belud have visited Mautanani Island but it is doubtful whether any observations except bare official 
recorts are in existence. There is in lact considerable doubt as to how many collections are made each year on the island: even recent reports vary.

2. It should be noted that existing nesting colonies are situated in a great variety of situations. Small coastal islands are always possibilities but in direct opposition to this the nests may be found in jungle many miles from the sea. Fixtensive flat areas unay be left ont of account but isolnted hills should be regarded as promising.

Fxclusive of the caves on Gommtong Hill which are the most important in the country the known nesting colonies are ronghly grouped together in Schedules II and III of Ordinance XII of 1914. T'o these should also be added the Berhata Island caves vide G. N. 325/28.

Taking advantage of this published information the following uncritical list is obtitined. It is almost certainly incomplete:-

1. The Madai, Segalaong and Baturong group of caves.

2. The Seguna Caves.

3. Gaya Island (East Coast).

4. Kielumpong River.

5. The Senobong Caves, including Pengharapan and Lingutan.

6. The Melikop Caves.

7. Mantanani Island.

8. Pahuı Batu (Interior).

9. Kunamut.

10. Melobong.

11. Bod Tai Caves.

12. Materis Caves.

13. Batangan Caves.

14. The Berhala Island Caves.

15. The Gomantong Hill Caves.

\section{THE GOMANTONG CAVES.}

From the commercial point of view the caves in the limestone hill of Gonantong are the most important in the territory. Gomantong Hill is situated in the middle of the forest reserve of that name and, in a straight line, less than twenty miles south of the town of Sandnkan.

The caves have often been visited and several descriptions have been published.

The height of Gomantong Hill has been variously estimated up to a maximum of 1,200 feet. The difficulties of its ascent have been exnggerated by one author: from base to summit the hill presents no trial greater than a steep walk or an easy scrumble over boulders. From the summit there is a good view of Sandakan Bay and Pulau Bethala and, if visibility is good, Mt. Kinabalu can be seen. The caves, in the main, consist of two large chambers, one above the other. It has been said that the floor or the upper cave forms the roof of the lower cave and this may well be so. There seems some doubt as to whether the two main 
caves have any direct communication but it has been suggested that a deep hole in the upper cave leads into the lower cave.

The lower cave is known as Simud Itam, the upper cave as Simnd Puteh. Other names, well known and commonly used in conversation are applied to certain parts of the caves, usually lateral recesses or shafts leading to the top of the hill. The use of these names is at first very confusing is the natives emphasize the entity of such places and are relnctant, probably on account of collecting rights to admit that the smaller is part of the greater! 'The best known of these secondary names is Belongbulud which is merely a shaft leading into Simud Puteh from the summit of Gomantong Hill.

The entrance to the lower cave is at the foot of the hill near, and level with, the bank of a sinall stream. The large porch-like entrance opens into a spacious lofty chamber strongly reminiscent of a cathedral nave.

Sufficient light is admitted through large holes in the domed roof to enable one to see without lamps. The main features about the lower cave are that certain sinaller caves or depressions open into it on the left and that another, dark, unexplored, but apparently large, eave runs off from a point approximately opposite to the entrance. 'This subsidiary cave is said to be inhabited entirely by bats.

The first part of the cave is about one hundred yards long. The highest point of the "nave" has been estimated at four hundred feet. "The bat cave has been said to run back for two hundred yards: its entrance is about thirty yards across.

All these measurements are probably only the roughest of approximations.

The- upper cave or Simud Puteh lies above the lower cave. To reach its entrance which is a gap about fifty feet wide and thirty feet high it is necessary to retrace one's steps from the lower cave and climb the hill.

The interior of the cave, away from the entrance, is intonsely diark and lights are necessary.

Simad Puteh is a long, namow, irregularly shaped cave culminating in a dome-shaped chamber. Its length has been estimated at four hundred and fifty yards and its height, not great near the entrance has, in the end chamber, been variously placed between 540 and 850 feet. Large holes or shafts enter the roof at the end of the cave one of which opens out on the actual stmmit of the hill.

Rough sketch maps of the upper and lower caves were supplied by Mr. S. G. Holntes in a report to Government dated 8th Feb. 1923, and much information of toporraphical interest concerning the small caves in the vicinity of Gomantong is contained in a report issued by the Conservator of Forests.

Any detailed research carried out in the Gomantong cares whether it be in connection with the distribution or yearly census of nests or exploitntion of the guano deposits or along any other channel would be impeded by the total absence of reliable data and mą̧s.

A prelininary plan of the Gomantong eaves would not be dificult to make. The attached sketch map prepared by Mr. and Mrs. Cedric Dover, under the auspices of the F. M. S. Musenms Department, represents the Batu Caves near Kuala Lumpur. 'I'here are no nests in these caves but $I$ have coloured and atded notes to the sketch on the supposition that the caves were inhabited by swiftlets. The system is offered as a suggestion to any officer who may attempt the wort in future. 


\section{COMMUNICATIONS.}

The commonly-used line of communication between Sandakan and Gomantong is by way of Bilit on the left bank of the Kinabatangran River.

First day. 'T'he time of departure from Sandakan depends on the state of the tide in the 'Trusan (a narrow waterway connecting Sandakan Bay and the Kinabatangan River) unless it is preferred to go round to the mouth of the Finabatangan by sea. In any case it is necessary to sleep the night at Bilit, a kampong on the left bank of the river.

Second day. The second stage of the journey begins with a short walk across a fairly steep ridere at the back of Bilit and then down to a point (Pintasan) on the River Menungal. 'The Menngal is a stream flowing approximutely parallel to and north of the Kinabatangan which it enters between Melapi and Sukati.

The time taken for the journey along the narrow Menungal in small boats (robangs) depends entirely on the state of the river. The record time from Pintasin to Pangkalan, the landing place for Gomantong Hil! is five and three quarter hours but if the river is very low it may take four or five days and the boats have to be hauled most of the way. It is usual and convenient to spend the night at Pangkalan.

Third day. The distance from Pangkalan to the caves is about three miles or a little less and takes between one and two hours, according to the state of the path. In an ofticial report " 30 minutes" is given as the time but this is phenoInenally fast travelling. The caves can be inspected, the hill climbed and the return journey to Pangkian made, in comfort, on the third day.

If conditions on the Menungal are exceptionally favourable the whole jouney from Bilit to the caves can be miale in one day but the following must be regarded as a normal itinerary for a visit to Gomantong from Sandakan.

Ist day. From Sandakan to Bilit by launch.

2nd day. To Gomantong Pangkalan by "gobange."

3rd day. To the cares and back to Pangkalan by foot.

4th day. 'To Bilit.

5th day. T'o Sandakan.

The followingr points may be noted in connection with this line of communication.

Above Bilit the Menungal soon narrows down to a small shallow strean much overhung by branches, full of fallen trees and other obstructions. Except when the water is favourably high, the boatmen are constantly getting out of the boat to krang it over shallow places and to clear the stream with their parangs.

It seems curious that the inhabitants of Bilit have not, for their awn alvantage, cleared a permanent route to the caves.

Local opinion holds that such a course would be useless, that periodic floods inevitably block the stream, and that the very nature of the stream and its banks necessitates the clearing process almost as many times as the waterway is used. $\Lambda$ brief survey of the ground indicates that local opinion is well substantiated.

There is a shelter at Bilit Pintasan and a lialting bungalow and cooly lines at Gomantoug Pangkalan. At the foot of Gomantong Hill is a well built store 
house which can be used as a rest house. Water and a bathing place are conveniently near and rongl shelter's have been erected by the men who visil the caves to collect the nests.

In dry weatber the joumey from Gomantong Pangkalan to the caves is very attractive. The path is good, in some places it could atmost be called a rond, although there are some soft patches here and there. It leads through the heavy virgin forest of the Gomantongr Forest Reserve. This reserve would form an admirable "nature reserve". On the present occasion tracks of elephant, tembadau, rusa and pig were seen. A pair of orang-utans were resting in a tree not far from the path and birds were abundant.

The river journey between Pintasan and Gomantong Pangkalim is about eight and half miles in a straight line but very appreciably more when the course of the stream is followed.

In any consideration of the line of communication between Sandakan and Gomantong Hill the question immediately arises as to why such a roundabout route is followed and an obvions, more direct, way of approach ignored.

It may be that visitors to the caves are so few that it has not been considered worth while to nake special arrangements and that, at the noment, it saves trouble, although not time, to travel by way of Bilit where experienced natives and boats are available.

In the event of any future active administration of the caves, involving more frequent official visits such an argument would fall and the feasibility of making a jermanent approach to Gomantong via the Sapagaya river must never be forgotten.

It is said that a launch can get to the timber workings on the Sapagaya river at high tide: a rentis to Gomantong Hill is then necessary.

This short route to the caves is comparatively well known. As long aro as 1886, a writer in the "British North Borneo Hearld" (IV, p. 94) recorded making the return journey in one day. "At 11.30 a.m. we started to walk back ( $i$. $e$. from the caves) to the landing on the Sapagaya River and arrived there at 4.30 p.m. We were a long time in getting down to the river to the stean launch as the river was low and some fallen trees blocked the path of the caves. However, we got off by 8 p.m. and arrived comfortably at Sandakan about 11.30." The same writer recommends future visitors to the caves to take at least three days for the excursion!

From the above remarks it will be seen that under the most favomable circumstances the return journey to the caves via Bilit takes at least four days, but this is a minimum expenditure of time not normally to be attained. Six days is more probable and even longer quite possible. From enquiries, admittedly rather superficial, I wis told that the chief objection to the Sapagaya route is that the country between the Sapagaya River and Gomantong is flooded at certain sensons.

Whatever the conditions are in that limited aren it seems incredible that they do not apply in equal force to the country between Bilit and Gomantong. The map suggests no special adverse conditions and in the event of visits to the eaves becoming irequent it is a sine qua non that the Sapagaya path should be reopened. 


\section{XI. 'IHE FOREST RESERVE.}

The Forest Ressrve has been established at Gomantong. It is four miles square and consists of 10,240 acres. This is a move in the right direction although it cannot yet be stated categorically that a forest reserve is essential to the welfare of the swiftlets.

The food of the birds consists of small flying insects not restricted in habitat to heavy forest and it is certain from first hand observation that the birds wander far in their foraging excursions.

It is certain, however, that the reserve does fulfil useful functions and should therefore be maintained.

It preserves the caves in isolation, regulates the approach of strangers, and generally facilitates control of the area. To allow timber cutting by engines in the immediate proximity of the nesting caves, indiscriminate shooting in the neighbourhood or the establishment of permanently occupied cooly lines in connection with any commercial renture would be a most hazardous experiment.

It is good policy to make reserves: they need not be too large. The Reserve should be regarded purely as a means of isolating the nesting colonies thereby making control ensy and eliminating the possibility of interference, the results of which cannot be foreseen with any certainty: they should not be regarded as indispensable ecologically:

\section{XIT. THE YEARLY CYCLE.}

The success of the birds' nest industry and indeed its very existence depends on the fact that the swiftlets persevere in their attempts to rear a brood in the face of systematic persecution, $i$. e., robbing of their nests and eggs but this is not the place to consider the ethics of the question. When at last the birds are allowed to hatch their eggs they are content and make no further attempt at nidification until the next season.

It is instructive to note the progress of events throughout the year and, most important of all, it may be noted that the yearly cycles of the two productive species of swiftlets are not coincident.

Collocalia fuciphaga. - T'he "season" is opened by the builders of the profitable white nests. They start to build in December and the nests ate all finished in March. Egrgs, however, occur as early as 28 th February and the harvest of the first crop of nests is berrun at the end of February and is continued for about twelve days. The second nests containing egrgs are ready for collecting fifty or sixty days later, and harvested in May. The birds are allowed to hatch their third lot of egrgs and the third collection of nests is not taken until the young are fledged about the niddle of July,

Collocalia lowi.-This species nests rather later in the yenr than C. fuciphaga. The first black nests are begun in January and collected in April and May, The second crop is taken in July or August.

Both species are comparatively regular in their labits bat it seems agreed that abnormal weather conditions of any kind tend to make the nests late. 
At Gomantong it is customary to collect the white nests three times a year and the black nests twice a year. It is not considered worth while to gather a third crop of black nests especially as this would mean a special trip to the caves.

The swiftlets are not truly migratory although they are subject to a certain amount of local movenent when not breeding. According to iny informants, Gomantong is a permanent residence for a large number of birds throughont the yen:. The old nesting sites are used as roosting places by the non-breeding birds. Local opinion is divided as to the numbers of the birds. Some say that they have been constant for fifty years; others that more birds now nest in the caves than formerly.

It is certain that in any one year a number of birds do not steceed in rearing a brood and that not all are persistent or virile enough to withstand the loss of two nests and perhaps two clutches of eggss.

One senior inhabitant of Bilit considered that of every ten birds robbed of their first nest, only four eventually reared a brood. The difficiency in the species is of course made up by the young birds which probably breed before they are a year old.

It is said that years ago, owing to a mistake, a fourth collection of white nests was made. These were few in number, bad in quality and mixed with many feathers. The following season the numbers of the breeding birds were sadly depleted. It is now suggested that :-

(1) Under no circumstance should more than three collections of white nests be allowed in a "season."

(2) If on any occasion the collectors wish to gather the third crop of black nests no official objection should be raised.

(3) Any sudden decrease in the numbers of the birds or a serious shortage in the crop of nests for any one year should be combated by the immediate enforcement of a close senson which for convenience can be fixed in factors of one calendar year 1st January-31st December.

In the East Coast Residency white nests are collected in the middle of January, at the beginning of Match and the beginning of May. Black nests are gathered in February and July. This information is contained in a letter written by the Resident of the Lisst Const and dated 1st January 1925.

Information about Mantanani Island is vague. According to official records in 1924, the system was to make three collections yearly but the present District Officer states that nests are collected four times a year.

The variation in the dates of the collections in different localities is extremely difficult to account for and although its existence cannot be denied I suspect that laxity of observation and expression will be found to account for some part of the discrepancies as well as the monsoon argument put forward by one Government Chief.

The dates and periods outlined above for the Gomantong Caves are, it is believed, substantially sound, althongh not obtained by direct personal observation. 
From year to year a certain amount of variation is to be expected but it is ditficult to see why the breeding colonies should vary individually.

If the birds are allowed to rear a brood in their first nest they will build no more that season and economy in collecting is therefore to be attained by observing the following points:-

A watcher should be stationed at the cave to grive warning that the nests are nearing completion and that eggrs are being hid. 'T'his course is followed (in theory at least) at Gomantong.

The journey to many of the eaves is long and involves much preparation and it seems reasonable to suppose that when the workers reach their objective they collect whatevel nests are to be had even at the risk of cutting the profits soniewhat. A slightly larger profit involving a double joumey and preparation would scarcely be an attractive proposition to the Sungei people.

Various names are applied to the collections or the period of the collections.

"Papas," "Penangah" and "Ekor" apply to the first, second and third collections respectively but they do not appear to be strictly parallel in origin and application.

"Papas" is a Sungei word meaning " the first collection of nests." "Penangah" is Sulu for half. On Mantanani Island the first collection of the year is called "Pengalasahan" which is succeeded by the chief collection of the year known as "Bunga tahun." A subsequent collection seems to be known as "Pahabissan."

I can make no recommendations with a view to increasing the average quality of the nests or the proportion of white nests.

\section{FOOD OF THE SWIFTLETS.}

The stomach contents of a number of swiftlets were sent to $\mathrm{Mr}$. H. M. Pendlebury, Systematic Entomologist of the Federated Malay States Musenms Department, who kindly reported as follows:-

"The material consisted almost exclusively of winged Ants (Hymenoptera) belonging to the subfamilies Myrmecinae and Camponotinae: the only determinable species were Colobopsis stricta Jerd, which was dominnt, and Colobopsis augustata Mayr., which was less numerons. All the other specimens were partly recognizable as belonging to species found in jungle and open country; by this is meant that none of them makes caves its exclusive habitat.

There were also remmants of two small Dragon-flies apparently referable to the genus Drepanosticta; and also those of a small green stink-bug, undoubtedly Plantia fimbriata.

Both these are open country insects only:

Were any steps to be taken in destroying jungle in the immediate vicinity of the caves, it would mean that insect life would be more abundant for a time, i. $e$, when the jungle was being felled and distmbed; after that there would be a scarcity which would camse the birls to go further afield in search of food. As a matter of fact, winged ants, which seem to form the bulk of their sustenance often flight in the evenings and early mornings, just when the birds are returning and leaving the caves." 


\section{INFANT MORTALITY.}

The only concrete proposal that can be put forward to incrense the number of the swiftlets is one to reduce the heary rate of infant mortality in the Gomantong Caves. It is believed that this is one of the most inportant recommendations contained in this report and if carcied out it can hardly fail to increase the bird population of the caves.

The death rate annong the young swiftlets is high. At the time of the recent visit most of the young were nearly fully feathered : at this stage is their habit to leave the nest and cling to the walls of the cave. Iiather more advanced juveniles were trying their wings on their first flights. The early fledging period is an extremely critical one for the young swifilets. Many fall to the ground and cannot rise again: others are jostled out of the nests or lose their grip on the wall of the cave. All perish miserably, drowned or smothered in the guano, eaten by rats or starved to death. In addition to many young birds in various stages of helplessness, the number of corpses bear witness to the many deaths in the caves during the tledgring period.

A proportion of these unfortunate young birds can certainly be saved by the simple process of throwing them into the air if they can fly, or replacing them on the rock face, as high as possible, if they cannot fly: in other words by griving them a second cluance of life. Their original unisfortme was in many cases accidental and abstruse theories concerning the advisability of artificially assisting those individuals, presumably weak and already eliminated by nature, need not enter into the practical politics of the Gomantong cave at this early stage of human interference. There is accommodation for double the present bird population in the caves.

The actual fledging period, i.e. the critical time when the death rate is highest, is probably only a few weeks in duration although specially directed observation is needed lere as individual irreguhrities in the times of luatching and quitting the nest must be expected.

A conscientious man should be stationed at the caves during this period to act in the uanner indicated. He should assume duty when the first young birds are becoming feathered and showing signs of leaving the nest and all birds found on the ground should be taken back into the caves and treated in the mamer indicated above.

It is important that the workers should not be allowed to waste life by collecting the third crop of nests before the young are fledged. A former District Ofticer of the Kinalatangan said that this was always done when supervision was withdrawn.

The above remarks have special relerence to the Gomantong Caves but the infant mortality in the Lahatd Datu caves is also notoriously high.

\section{OTHER INHABITANTS OF THE CAVES: ENEMIES.}

The swiftlets are not the only inhabitants of the caves for countless number's of bats are also found therein and other smaller creatures as well.

Of the smaller inhabitants cocliroaches and other insects, centipedes and spiders are perhaps the most conspicuous and all can at once be dismissed from 
further participation in this report as can the "vermin" (the "beel-lungs," of a repport in the Riesident's office at Sandakan!).

There are some rats in the cave and a small carnivore ("musang") is at least a casual visitor but these also can be disregarded and are never likely to become a serious menace.

All the bats collected were small Microchiroptera (insect-eaters) but fruiteating species are quite likety to occur. In the lower cave there is as mentioned above a large dark, subsidiary cave which seems entirely occupied by bats but they can also be seen clinging to the walls near the nests. It seems that in the Gromantong caves there is room for both birds and bats and there is still plenty of unoccupied space. In some of the smaller caves of the Kinabatangan the bats are saill to dislodge nests by attempting to eling to them and it has been surryested that this is one of the reasons why the production of the suall caves is not regruliut.

This is the only "crime" that has been registered against the bats, a fortunate circunstance because it would be difficult, if not impossible, to deal with them by any method that would not injure the swiftlets.

As a matter of interest it may be mentioned that during the course of these investigations we were privileged to watch the famous nightly exodus of bats from the top of the cave.

Two observers estinated that three thousand bats per minute left the cave and that the stream continued for half an lour.

The serions enemies of the swiftlets are latge birds of prey, especially the Braluminy Kite numbers of which are always to be seen near the caves: the kites increase in number when the young birds are fledged. Bats are aldso taken by these pests and perhaps form the greater part of their food but the swiftlets also suffer and young and old alike are carried off. We actually saw this happen and also found two newly-killed adult birds that had been struck down by hawks and not carried off. Possibly they managed to free themselves and died later.

Indiscriminate of castal strooting by a native is not likely to thin the numbers of the kites appreciably and a former experiment was not successful. As cau be innugined most of the ammunition supplied was used for shooting mousedeer. A skilled persevering gunner could do a useful amount of damarge in a week or two but it certainly secus wrong to shoot regularly near the mouth of the cave. It wonld be a dangerous precedent to introduce steel trap into the country; such instruments are furthermore barbarous things.

The ideal way of doing the maximum amount of damage in the minimum time is to find the nesting colony and destroy the eggrs and parents. The nests are placed in tall trees and a colony almost certrinly exists near Gomantong or somewhere between Gomantong and the const. 'The kites are not migratory birds in the truest bense and the Gomantong thieves bave quite likely been bred and 
born in the neighbourhood of the caves. Once their number was retnced or the local stock exterminated it would take a number of years for another locial strain to establish itself by a slow influx.

'The Brahminy Kite and its egrs should be outlawed and chased as "vermin." It ean lye shot conveniently in Sandakan Bay. No sentiment need enter into this action as the species is common over a wide rancre and is not in the slightest danger of extinction.

No other practical suggestion can be made other than that a cheap donblebarrelled, twelve-bore gun should be kept in the Government office at Bilit with a supply of No. 4 shot. It could be borrowed by every responsible person visiting the caves and the number of kites would certainly be reduced. T'o many officers the shooting would provide a welcome break to an otherwise boring journey. But all users of the grum should be warned agninst shontingr the Snake-birds or Darters (Anhinga rufa melanogaster) which frequent the River Menungal or the benutiful stork-billed kingfishers which are more numerous between Bilit and Gomantong than in any locality we have visited.

It must not be understood that the kites are a plague at Gomantong or that the matter is urgent. There are a number of kites always there and as they work destruction they are best dead. The propasal pat forward above would meet the case and be sufficient to keep their numbers down.

\section{GUANO AND EGGS.}

Tchas been suggested that two additional though small sources of revenne might perhaps be provided by the guano deposits in the caves and by the egrgs a large number of which are thrown awa every year.

Although several possible avenues have been explored it is rergretted that no practical suggestion can be made under this heading. References in early numbers of the "British North Borneo Herald" show that the possibility of utilizing the guano was considered many years ago. A description well worthy of study is contained in the said Journal, III, No. 1, March 1884, p. 7.

I understand that the Forestry Department has also investigated the grumo beds of the caves but owing to the absence of the officers of the Department when $I$ was in Sandakin I could gain no confirmation of this.

\section{METHODS OF COLLECTING THE NESTS.}

The nests either singly or in small clusters are attached to the bare walls of the caves: it seems that no definite attempt is made to take advantage of natural projections of the rock.

Nests of three species are, broadly speaking, found side by side; but the nests of one species frequently occur in patches and sometimes a comparatively large area is occupied solely by one kind of nest. It is difficult to account for the birds" choice of sites. Some building areas are fairly exposerl and the nests can be seen. 
Other groups of nests are estublished in what appear to be recesses or concavities in the roof and in some cases the nests are in total darkness.

But wherever the nests nre placed they have one feature in common for al are normally inaccessible. Some can be reached by loug bamboo poles : to obtain others perilous climbing is necessary. The majority can only be oltained after a high and dangerous elimb and looking up from the ground to the heights of the carerns it sometimes seems incredible that men can perform the work.

The climbing apparatus is extremely well made, the main ropes consisting of plaited rattan. The plant consists mainly of rattan ladders and climbing galleries.

The methods of the climbers vary. Sometimes they descend into the inky darkness of the cave through a hole in the roof. At other times the long ladders are used to climb the walls of the eave up to a certain point, after which the climbing galleries are lanuled up and fixed in position. 'The nests are placed in baskets by the collectors and after the descent, threaded on a thin rattan and bundled up. More detailed accounts of the actual climbing have appeared elsewhere. When necessary the workers use torches for travelling and long thin candles for the actual collecting. It is an obvious fact that many nests are not collected because they are inaccessible. This inacessibility depends on two factors, firstly bad lighting, and secondly the position of the nests which defies even the boldest of the climbers.

\section{LIGHTING.}

The climbers admit that the thin candles used by them are not strongr enough to illmminate even the areas they work regularly, that they are a nuisance to manipulate and are constantly being extinguished by dranghts. Furthermore and most important of all they admit that large sections of the roof cannot be examined because of a lack of lighting appliances. Fantastical though it may sound it seems that the possibility of lighting the caves should be seriously considered. A low-power electric light on a very long flex at once sugrgests itself and the expense would only amount to a few hundred dollars. If an electrical engineer approved the feasibility of the scheme the experiment should be tried for a season or two in one of the smaller caves of the Kinabatangan.

\section{Criming.}

To attempt to assist or interfere in any way with the skilled work of climbing seems a questionable measure but it is possible that an engineer could give assistance to the climbers and enable them to reach parts of the caves hitherto regarded as inaccessible.

The provision of iron rings or staples, the walls of the cave being plugged at selected places for their insertion seems the most obvious method of rendering such assistance. That the climbers were not adverse to the sugrestion of stch aid was apparent at the time of my visit.

It is therefore suggrested that a trained engineel should visit the caves, firstly: to consider the possibility of introducing a lighting system to replace or supplement the present candle methor and secondiy to consider the feasibility of assisting the climbers with methods and apparatus. The reply to any query concerning the value of such experiments is contained in the monetary reburns of the Gomantong 
caves. In 1929 the Government share of the proceeds from these caves amounted to $\$ 45,685.22$ : the total proceeds were $\$ 91,313.44$. Considering the limited aren of the caves and the obvious fact that only a small portion of them is used by the birds, the benefit to be gained from the exploitation of even an additional twenty square yards of roof or a hither to unexplored hole is obvious. The climbers admit that they know places where nests are plentiful but unworkable.

The actual climbers (Orang Sungei) are inhabitants of the kampongs Bilit and Sukan on the Kinabatangan River. Not all the workers who visit the caves are capable of doing the high climbing, comparatively few "tukangs" having this distinction. The men with no hend for heights are employed on the ground work. Fatalities anong the climbers during the harvest are not unknown.

\section{MARKETING.}

In the forerroing sections of this report various suggestions have been made with a view to increasing the yield of nests but the writer considers that, regarding the industry as a whole, his suggestions are only of minor importance and that if any great incrense of revenue is expected it must be done from the marketing side. The industry should in fact be subjected to the scrutiny of an experiencer man of business with an intimate knowledge of local markets.

The writer must perforce content himself with a statement of facts likely to be of use in this connection.

After their collection in the caves the nests are bundled up (white and black are liept separate) and after detailed weighing formalities at the enves and at Bilit or Sukau they are taken to the Sandakan Customs by boat, weighed agnin and stored in a godown. As soon as possible they are sold by tender to local Chinese who ship them to the best market. A very small quantity is kept for local sale but most of the nests are exported to Hong Kong.

It would appear that little or no attempt is made to clean the nests in Sandakan, but that they are sorted and spread out to dry (in a building, not in the sun ) and shipped as soon as possible.

It is said that in the past one firm cleaned the nests before export but that the practice has been discontinued.

Another method involving the use of sulphur made the nests very white and therefore commercially attractive, but this method did not find a great deal of favour as the nests were subsequently liable to taste of sulphur.

Hong liong is of course the obvious port to which the nests should find their way as most of the Sandakan Chinese have their regular business connections there. The Gomantongr nests are sold in Sandakan; those from the east const are sold in Lahad Datu and the Mantanani crop in Jesselton or Kudat.

The Commissioner of Customs and Trade provided the following information :White nests sold in Sandakan average $\$ 7.10$ per catty.

Black nests sold in Sandakan average $\$ 200-250$ per picul.

In Lahad Datu the prices are rather higher :-

The white nests average about $\$ 15$ per catty.

The blach rests average $\$ 300-400$ per picul.

In February of this year I could not buy white nests in Singapore for less than $\$ 15$ per catty and these were of poor quality. Nests of good average guality 
were $\$ 30$ per catty. The best white nests on the same day were priced at $\$ 64$ per catty and these were not so fine as those from Bethala Island. Some of these nests were said to have been imported from Borneo.

The best white nests from Pulau Berhala are sold for \$30-50 per catty, or even more, but the qumtity is very small.

Very bad quality white nests from Gomantong are sometimes sold for the very small figure of $\$ 3.50$ per catty. These are usually wet nests and much discoloured. A small quantity of exceptionaliy fine nests from Gomantong may command $\$ 20.00$ per catty. The white nests of the east coast command a higher price than those of Gomantong because they are said to be of a superior quality. This may be because of a specific difference in the birls, but against this view is the fact that the black nests also average hirger in price and they are certainly made by the same species as the black nests of Gomantong.

Various experiments in marketing have been made. 'T'he East Coast nests have been brought to Sandakan for sale and the Gomantong nests have been sold in Singapore. In the former case the nests fetched rather less than usual and in the latter case the experiment was a falure because of the expenses incurred by the large number of interested parties who followed the nests to Singapore.

The chief weak points of the system broadly outlined above are firstly that the loop-holes between the caves and the Sandakan Customs are many.

Secondly, even to one unversed in commercial affairs, the fact that the price of the nests is controlled locally seems too obvious to be ignored.

'The remedy for leakages in the line of communication is of course increased supervision but the writer does not wish to enlarge on this subject.

The marketing weakness is less easily dealt with and seems to hinge on seeking opportunities for wider conpetition in selling. But it may be that political factors intrude themselves here.

As an assistance to any fuller enquiry into what may be called the business side of the industry the figmes in the following section may be useful.

\section{XIX. 'TRADF,}

The following information is extracted from published statistics:

In some cases the trade returns seem uncritical and owing to the extensive transhipping which takes place at Singapore and Hong Kong it is difficult to trace the actual sources of supply, particnlarly at the latter port: they at least enable a general impression of the whole trade to be formed. The following facts are based on the period 1926-28.

China is of course the chief importer and consumer. The total gross imports of nests into that country for the three year's were:- $79,837,77,377$ and 56,477 catties.

The two main sourees of supply are Hong Kong and the Straits: the latter region always provides far mote nests than Hong Kong, sometimes twice as many or even more.

Minor sources of supply are the Dutch Last Indies (direct) Macao, French Indo-China, Sim, British India and Japan (including Formosa) but of these only: 
the imports from the Dutch East Indies are large enough to merit special consideration: in quantity they amount, rouglyly, from one-tenth to one-quarter of the import from Hong Kong.

British Malava imports most of its nests from Sarawak and the 1)utch East Indies and only a relatively suall quantity direct from British North Borneo.

\section{LOCAL ORDINANCES.}

'The existing law specifically relating to the edible birls' nest industry is contained in Ordinance XII of 1914 ; Notification 142 of 1914; Gazette Notification No. 9 of 1914 and Gazette Notitication 325 of 1928.

The essential points of the law may be epitomized as follows :-

1. All caves, known and unknown, are the property of the Government except those hitherto recognized as private property.

2. The discoverer of a new cave has the sole right to work it for five years: the Govermment gets a royalty of five per cent.

3. Only life interests in caves are allowerl : interests cannot be alienated.

4. Contractors are appointed to work caves not private property.

5. Detailed permits are necessary to enter or take nests from any plince and an authorized certificate signed by a Government Agent must be confirmed by" a Government ofticer before any sale is complete.

6. Debts must not be paid in mests and all nests must be exported or consumed during the year of collection.

7. Caves recognized as private property are subject to an anuml royalty of 10 per cent of the nests collected.

8. The problem of part owuership on the east coast is simplitied by the keeping of a Government Pegister in which the names of all persons entitled to participate in the profits of the caves are included. The important Gomantong caves which are Government property are worked by a Contractor, the essential features of whose contract are:-

(a) He must collect all nests and deliver them to Government. He is generally responsible for the proper management of the caves.

(b) He is paid 50 per cent of the gross amount realized by the sate of all nests subject to certain minor adjustments.

(c) He can work a cave for himself and sublet any cave to cortain privileged natives (becanse of hereditary interests, etc.).

\section{XX'T. SUMMARY.}

From the evidence afforded by the present rather superfictal enruily it seems certain that the birds' nest industry of British North Bortsco conld be exploited yet further and made to yield increased profits to the workers and revente to the Government. Improvemente to this end can conveniently be grouped in two sections:-

A. Scientific Control and Investigation

B. Business Arrangements.

Althongh it seems apprent that some action can be taken in Section $A$ in increase production it is almost certain that any really substantial increase of reveute uust accruo from provisions to be uade under Section $B$. 


\section{A. Scinntific Control and Investigation.}

It is at ouce vecessary to emphasize the fact that in the very early stagres of this enquiry I realized the futility of attempting, in the time at my disposal, a detailed iuvestigation in to the ccology of swiftlets.

In thtee years a trained biologist should be able to produce a more or less exhaustive report on the sulject. In the event of the Goverumeut ever considering such an appointment I think that a young wan with a scientitic training and a taste for ornithology would find the appointment congenial. An excellent subject for doctorial thesis is provided. The salary, emoluments and privileges offered should be the samo as those of a junior officer of professional status in the service.

In the event of the Government not pursuiug this conrse the following comments and suggestions are offered :-

1. The keynote of all practical adninistration of the caves shonld be CAUTION.

The birds have bred there for many years and many remain in residence indefinitely. 'l'he industry is probably stable, but epidemical diseases are not unknown among birds and the extreme susceptibility of breeding birds to interference is well knowtl. The swiftlets have proved themselves very tolerant of human intervention but tho introduction of any new, unstapected element in their environment would be a dangerous experiment.

2. Under no circumstances should ruore than three collections of white nests be allowed in a "season".

3. Any sudden decrease in the numbers of the birds or a serious shortage in the crop of nests for any one year should be met by the immediate enforcement of a close season which for convenience cau bo fixed in factors of one calendal year, 1st January to 31st December.

4. To tuke the third crop of white nests before the young birds luave voluntarily vacated the rests is a sure way of extermiuating the species.

5. An attempt to reduce the present high rate of infant mortality should be made (Section xiv).

6. A qualified engineer could possibly assist the chimbers to reach parts of the caves bitherto regarded as inaccessible.

\section{B. Business Anthangements.}

The writer is not qualified to make snggestions under this heading but the great difference between the wholesale price paid for nests in Bonneo and the retail price asked in Singapore (the Hong Kong retail prices are not known) suggests that there is an inequitable division of a louge profit, the middle men getting more than their share while the workers and the Government get less. Here io may he noted that there is a recorded instance (not in linrneo) of the actual collectors of the nests having their profits rednced to such an extent that they ceased to work their caves. 




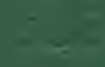

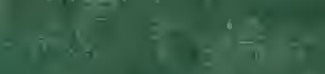

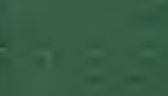

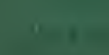

$-$
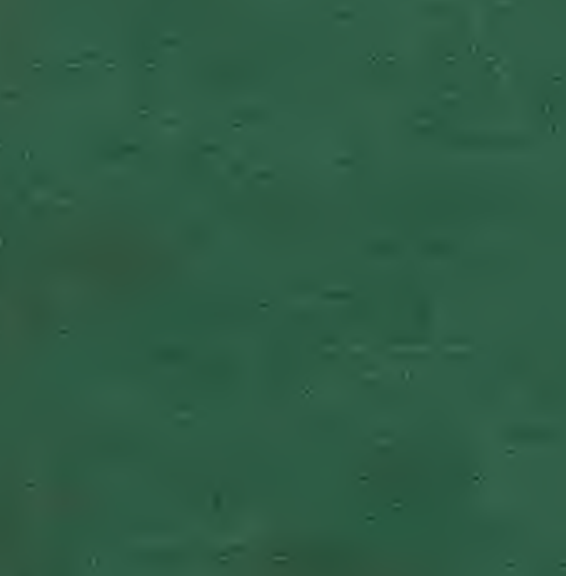

$\therefore=$

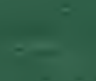

(1)

$=$ 